\title{
NEW TRANSNORDESTINA RAILWAY AND SPACE ORGANIZATION
}

\author{
BIACHI, Ana Paula Theodoro ${ }^{a *}$ MACEDO, Fernando Cezar ${ }^{b}$ *
}

(a) Phd Student in Economic Development, Space and Environment, State University of Campinas (UNICAMP). ORCID ID: https://orcid. org/0000-0001-6877-3585. CURRICULUM LATTES: http://lattes.cnpq.br/0462029779554770

(b) Phd in Economy. Professor Campinas State University (UNICAMP). ORCID ID: https://orcid.org/0000-0002-8690-2077. CURRICULUM LATTES: http://lattes.cnpq.br/6007792964190655

\section{(*) CORRESPONDING AUTHOR}

Address: UNICAMP - Cidade Universitária Zeferino Vaz, CEP: 13083970 , Campinas (SP), Brasil - Caixa-postal: 6135, Tel: (+ 55 19) 37885830 E-mail: apbiachi@gmail.com

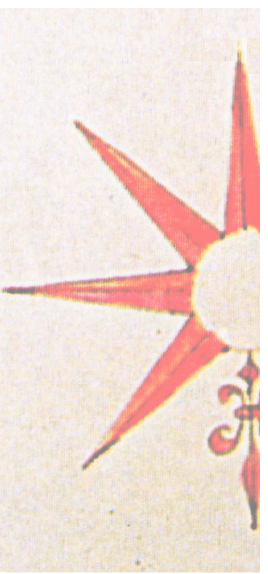

\section{RESUMO}

This text analyses the socioeconomic and territorial impacts arising from the Nova Transnordestina railway construction in the Ceará, Piauí and Pernambuco states. The hypothesis is that the investments in its construction have as main purpose to improve agricultural and mineral exportations, despite possible externalities over the region of its influence which covers not only the states where it is being built but also the region of Matopiba. For these reason, this text highlights the socio-environmental problems that arise from the project and the impacts on communities affected by its route. Methodologically, the text is based on bibliographical survey, documents related to the projects, journalistic information and interviews. Theoretically, it articulates the socio spatial formation concept with the pattern of capital reproduction concept, adapting them to studies of underdeveloped and dependent formations, such as the Brazilian.

Keywords: Nova Transnordestina Railway; Regional Development; Infrastructure; Territory

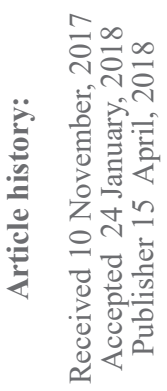

\section{ABSTRACT / RESUMEN}

\section{FERROVIA NOVA TRANSNORDESTINA E ORGANIZAÇÃO ESPACIAL}

Este texto faz uma análise socioeconômica e territorial dos investimentos da ferrovia Nova Transnordestina que corta parte dos estados do Ceará, Piauí e Pernambuco. A hipótese é de que esta ferrovia tem como objetivo principal atender as exportações agrícolas e minerais, apesar de possíveis externalidades positivas sobre a região de sua influência que abrange não apenas os estados cortados por ela mas, também, a região do Matopiba. Por isso, este texto destaca os problemas socioambientais que decorrem do projeto e os impactos sobre comunidades atingidas por seu traçado. Metodologicamente, o texto foi construído a partir de levantamento bibliográfico, documentos relativos aos projetos, informações jornalísticas e entrevistas. Teoricamente, parte do conceito de formação socioespacial e articula-o com o conceito de padrão de reprodução do capital adaptando-os para estudos de formações subdesenvolvidas e dependentes, como a brasileira.

Palavras-chave: Ferrovia Nova Transnordestina; Desenvolvimento Regional; Infraestrutura; Território.

\section{NOVA TRANSNORDESTINA FERROCARRIL Y LA ORGANIZACIÓN ESPACIAL}

Este texto es un análisis socioeconómico y territorial de las inversiones en la Nova Transnordestina ferrocarril que corta parte de los estados de Ceará, Piauí y Pernambuco. La hipótesis es que este ferrocarril tiene como principal objetivo satisfacer las exportaciones agrícolas y minerales, a pesar de los posibles efectos externos positivos en la región de influencia, que abarca no sólo los estados cortados por ella, sino también la región de MatopibaPor lo tanto, este documento pone de relieve los problemas sociales y ambientales que surgen del proyecto y los impactos sobre las comunidades afectadas por su trazado. Metodológicamente, el texto se construye a partir de los documentos bibliográficos relativos a los proyectos, información periodística y entrevistas. Teóricamente, parte del concepto de formación socioespacial y lo articula con el concepto de patrón de reproducción del capital adaptándolos a estudios de formaciones subdesarrolladas y dependientes, como la brasileña

Palabras clave: Nova Transnordestina Ferrocarril; Desarrollo Regional; Infraestructura; Territorio. 


\section{INTRODUCTION}

The objective of this text is to make a socioeconomic and territorial analysis of the investments in the construction of the New Transnordestina railway, a project that began effectively in 2006, when the first works were carried out in the Missão Velha / CE to Salgueiro / PE section. These investments are intended to complement the 4.3 thousand $\mathrm{km}$ of the railway network in the Northeast, privatized in 1997. It would thus retake the historical and secular discourse of a railroad connection in the interior of the Northeast that dates from the end of the eighteenth century, as pointed out by authors like Pinto (1947) and Camelo Filho (2011).

Although the official discourse maintains the pioneering idea of integration that, through the railway, sought to articulate the economic activities and the different regional spaces of the Northeast, the new railroad plays a less ambitious role and is a direct response to the international market pressures that deepen the Brazilian model of dependent underdevelopment and is linked to the production of commodities with a low added value. This reinforces the need to adapt the territory to the demands of the pattern of reproduction of the dominant capital in the Brazilian economy since the end of the twentieth century, increasingly linked to agricultural and mineral activities for export that require major infrastructure works, especially transport - such as the railroad under discussion herein - in order to dispose of its production located in the interior of the country. This is the hypothesis that guides this work.

The New Transnordestina starts in the municipality of Eliseu Martins / PI and will reach the ports of Suape / PE and Pecém / CE, which will be interconnected from a central junction in Salgueiro (PE). There will be 1,728 km crossing 81 municipalities in the states of Piauí, Ceará and Pernambuco, with an estimated cost of $\mathrm{R} \$ 11.3$ billion. The project is therefore linked to investments in the modernization and expansion of these ports and, on the other hand, to the expansion of the mineral and agricultural frontier of the cerrado, especially in the Matopiba region, which would allow the railroad to transport loads of up to 30 million tons / year of agricultural and mineral products for export from its area of influence, according to estimates from official documents and the operator Nova Transnordestina Logística SA - TLSA.

This text is divided into five parts, beginning with this brief presentation. This is followed by a discussion of the relationship between infrastructure and spatial organization, with particular emphasis on the role that the investments destined to diversification and the expansion of the modes of transport undertake in the present phase of accumulation of the Brazilian economy, strongly centered on the production of commodities for the external market. This role is not limited just to the expansion of export capacity and the reduction of the "Brazil cost" as traditionally presented, but also, because of the impact they have on the spatial organization of the country's regions and subregions. The next topic presents the features of the New Transnordestina project and is subdivided into a brief territorial and productive analysis of three States through which it passes. The fourth topic summarizes the main possibilities and the main problems faced in the execution of the project, highlighting the socioeconomic and spatial impacts raised to date. Finally, the text concludes with the final considerations.

This work is anchored in information obtained from public and private agencies, such as the General Comptroller of the Union (CGU), the National Association of Railways (ANTF), the National Department of Transport Infrastructure (DNIT), the Ministry of Transport (MT), the National Confederation of Agriculture (CNA), VALEC Engenharia, Construções e Ferrovias S.A., the National Confederation of Transport (CNT) and the Institute of Applied Economic Research (IPEA). In some of these institutions, in addition to the documents collected, interviews were conducted with some of their representatives.

Specifically, for the state of Pernambuco, field research was carried out with the main objective of understanding the articulation of the expansion of the agricultural frontier in the north-eastern Cerrado with the decision regarding investments in the construction of the railroad. Interviews were 
conducted with professionals from selected sectors in a strategic way, to obtain different points of view about the objectives and feasibility of the project, as well as more accurate information concerning this project in the state. To this end, representatives of the following institutions were selected: (i) public sector - Pernambuco Economic Development Agency (Addiper), Secretariat of Economic Development (SDEC) and the Governor Eraldo Gueiros Industrial Port Complex (Suape); (ii) private sector - Economic Consulting and Planning (Ceplan) and (iii) academia - Federal University of Pernambuco (UFPE).

\section{PATTERN OF CAPITAL REPRODUCTION, EXTERNAL INSERTION IN COMMODITIES, INFRASTRUCTURE AND TERRITORY IN BRAZIL IN THE TWENTY-FIRST CENTURY}

In order for this text to meet its general objective, it is essential that the discussion be based on an analysis of the relationship between infrastructure and spatial organization, with particular emphasis on the role that investments in the diversification and expansion of transport modes play in the current phase of accumulation of the Brazilian economy, strongly focused on the production of commodities for the external market. Thus, throughout this study, the aim is to demonstrate that such investments are not only limited to the expansion of the export capacity and the reduction of the "Brazil cost" as traditionally presented, but they become a fundamental tool for changes in the organization of the regions and subregions of the country.

\section{PATTERN OF REPRODUCTION, UNDERDEVELOPMENT AND DEPENDENCE}

Between 1930 and 1980, Brazil had an urban-industrial economy that transformed it into the most complex productive structure among the Latin American countries. This pattern of reproduction, which mirrored the emergence of more advanced productive forces in the interior of its underdeveloped and dependent economy, was characterized by the strong dynamism of the internal market that would reorganize the use and occupation of its territory in a manner that was very distinct from the primary export period prevalent prior to 1930.

Of the former regional archipelagos that were directly linked to the external market, with a port city as a node of a dendritic network whose hinterland was organized around it, the industrialization of the country promoted greater integration of the territory by articulating the internal market; an integration that was expressed in the increase of flows of goods, services, people, information and capital through an urban network that lost its regional character and subsequently took on a national and international projection, captained by the city of São Paulo that would gain metropolitan dimensions. In this process, the infrastructure financed by the national State, especially telecommunication and transport networks (mainly linked to the road system), as well as intra-urban investments, ensured, on the one hand, commercial circulation and the expansion of consumption and, on the other hand, the reproduction of the workforce, which demanded an effort to expand urban facilities. The spatial organization that emerged at that time was strongly metropolitan and concentrated in the Southeast of Brazil, which received the main flows of internal migrations, which were mostly rural-urban.

The crisis of the pattern of urban-industrial reproduction in the 1980s and the restructuring of global capitalism in the last quarter of the twentieth century changed the role of the country (and of Latin America) in the international division of labor. The manufacturing industry lost momentum and the process of de-industrialization underway in Brazil and in the region began, but it would 
become more evident in the twenty-first century. In contrast, agricultural and mineral activities and the segments of the manufacturing industry linked to them became more dynamic and would be the ones with which the country would increase its participation in foreign trade, a clear demonstration of its role in the international division of labor. The participation of agricultural and mineral commodities in the export agenda did not only increase with the relative fall in the participation of industrial products, there was also a rise in investments directed to these sectors, such as the Direct Foreign Investment (DFI). This was especially the cases after 2003, when the increase in global demand driven by the "China-effect" increased the internal dynamism of these activities, consolidating the new pattern of reproduction in the country that Osório (2012a and 2012b) calls the "exportation pattern of productive specialization" (post-1980) as opposed to the "industrial pattern" that dominated the previous phase (1930-1980).

As described by this author, "each pattern of capital reproduction presents specificities as to the use made of geographical space. Capital intervenes in the territory in different ways, according to the particular needs that its metamorphosis demands" (OSORIO, 2012a, p. 73). The notion of the pattern of capital reproduction enables a methodological understanding of "how capital reproduces itself in specific historical periods and in certain geoterritorial spaces, both in the center and in the semi-periphery and periphery, or in regions within each one" (OSORIO, 2012a, p. 40).

From the quotations above, it is assumed that it is only possible to analyze a socio-spatial organization within the general process of accumulation in the world, articulated in multiple scales and from the cycle of capital within the prevailing reproduction pattern at each point in time. That is, at each historical stage, there is a way of organizing production and circulation that redefines the use and occupation of territories, within an international division of labor that specializes and integrates national and local economies into a world economic system. Therefore, the predominance of a pattern of capital reproduction corresponds to a pattern of spatial organization whose form can only be grasped at more concrete levels of analysis that make it possible to reveal how the general movement of capital manifests itself effectively in the territory by altering or influencing the (re) location of productive activities, patterns of urbanization, migratory movements, policies (macroeconomic, regional, urban, etc.), the labor market and infrastructure investments, among others.

Each country, region or local area inserted in the general accumulation process is forced to adapt to the demands of the dominant pattern of reproduction that is peculiar to it within the more general movement of capital, especially in underdeveloped and dependent countries. Thus, a territorial (national and international) division of labor is markedly heterogeneous in which the parties are interrelated. In the transition from one pattern to another, the regional and urban dynamics in the countries are redefined. The spatial forms that emerge in each place are specific to their socioeconomic structures and move according to the process of reproduction of capital in each specific conjuncture. For Sormani (1977), from the general proposition that every human practice develops on a given space, whose qualitative and quantitative characteristics condition it, it is necessary to insist on the fact that this space takes on specific forms, dispositions and structures in each case that respond to the nature and historical specificity of the types of prevailing organization that order and legitimize these practices. Consequently, the study of the forms of the spatial organization of society, whether relatively spontaneous or voluntarily imposed, must necessarily be linked to the concrete conditions of the process of development of the dominant mode of production within a social formation. The changes that take place will determine the new conditions of use and conformation of the space, the role of each of the settlements, the way they interconnect and, finally, the internal structure of the different regions and the regional system as a whole (SORMANI, 1977, p. 160).

It is important to make it clear that the combination of natural and constructed elements determines the spatial organization that varies in each historical moment, moving in accordance with the socioeconomic transformations of society and with the interests that materialize in economic policy. Like Corrêa (1986), we consider here the terms territorial structure, spatial configuration, 
spatial formation, spatial arrangement, geographic space, socially constructed space or simply space as synonyms. It is important to understand that this organization accumulates inherited forms from the past, which makes it a durable, although constantly changing, fact. It is not only a reflection of society but an indispensable basis for its reproduction, which means that the present conditions are determinant for future conditions of reproduction of society, as the author points out. This puts social groups and the various fractions of capital that compete among themselves, within a same country in constant conflict over the territorial order that best guarantees their reproductions. In a federative country, such as Brazil, this process means the escalation of the regional dispute over access to public funds and the dispute between subnational federative entities for the location of capital and its investments and for the use and occupation of the territory.

It also means that spatial organization is largely a result of the macroeconomic policies and interests that define the country's articulations with the international economy, and hence of the class struggle established in each territory and marked by the specificities of each conjuncture. Table 1, adapted from Macedo (2010), synthesizes the processes of organization of the Brazilian territory in the three patterns of reproduction of capital described by Osório.

Chart 1 - Brazil: patterns of capital reproduction and spatial organization

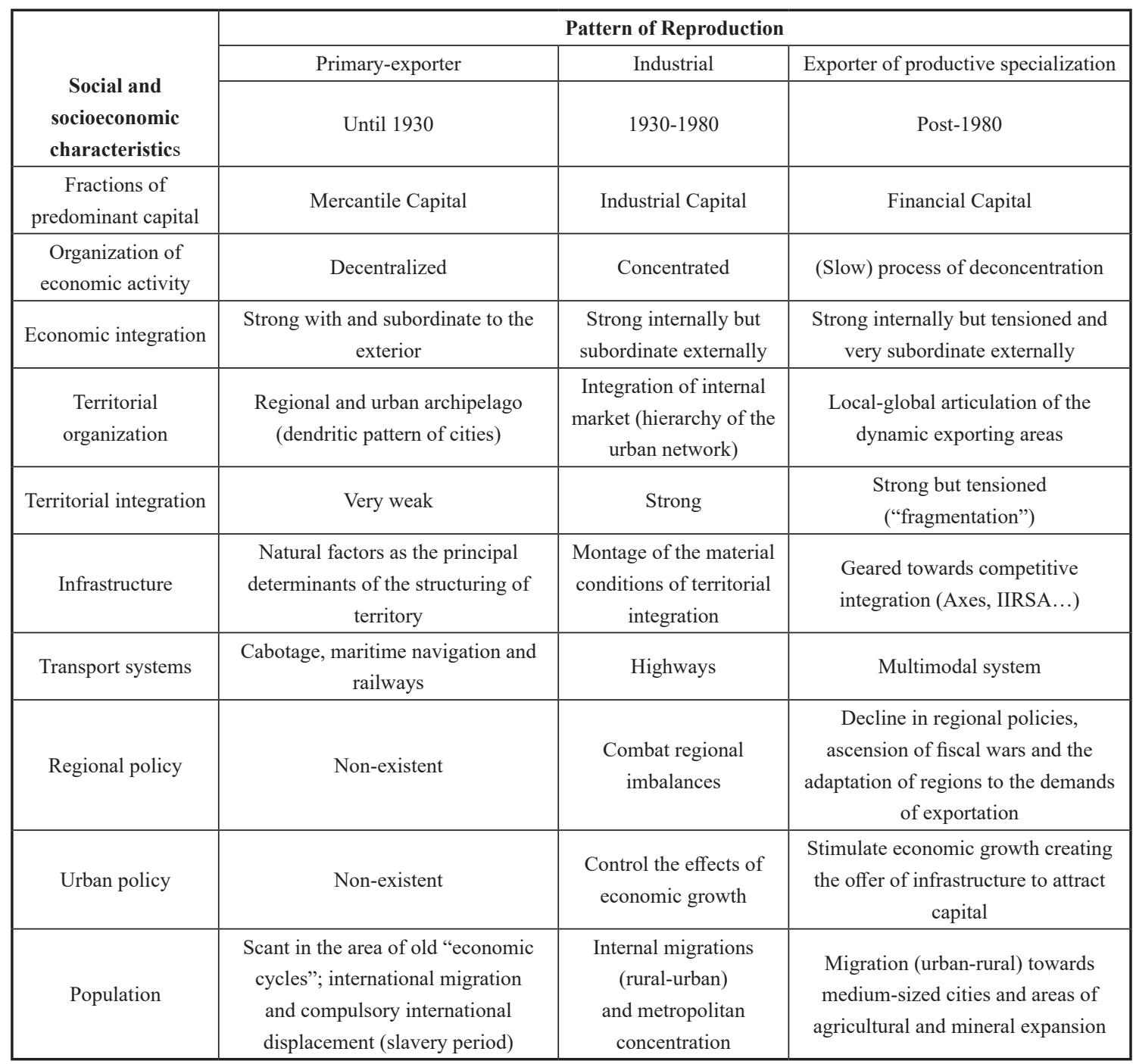

Source: Adapted from Macedo (2010). 
Despite their specificities, the different patterns of reproduction that emerge historically in Latin America, and in Brazil in particular, have a characteristic that has remained constant over time and has decisively influenced their spatial organization since the colonial past: the adaptation of the territory from external decision-making centers. This means that territory exists not to serve a nation project, but to meet the demands of primitive accumulation imposed by the colonial statute (at the beginning of its formation) and by the subsequent expanded reproduction of capital, within the framework of imperialism. That is why in each dominant pattern of reproduction there will be investment requirements for the (re)organization of the territory and specific territorial policies for this.

However, although subordinated to the general movement of capital, it is necessary to differentiate the specificities that mark the different socio-spatial formations, after all, "the search for tendencies and general traits should not suppose the loss of capacity to account for particularities" (OSORIO, 2012, p. 80). The new dominant pattern of reproduction in post-1980s Brazil, promoting the more intensive use of natural resources, directed agribusiness and mining activities to areas further from the industrial core (the Southeast, more specifically the state of São Paulo) where land and mineral resources were available, such as the Center-West region, the southeastern state of Pará and the Matopiba region.

Agricultural and mineral productions for export extended the interiorization of the country and caused alterations in the urbanization, which became more extensive in the territory. In the same way, there was a change in the migratory flows with the new dynamic areas growing in attractiveness. These areas established true local-global links, often articulating more with the external market than with the internal one, mediated by the large global players that have become decisive in their spatial organization, especially due to the pressures they exert for the construction of infrastructures that allow agricultural and mineral products to connect with international markets. According to Macedo (2010), summarizing Table 1, this is the new pattern of territorial organization that manifests itself in Brazil at the beginning of the twentieth century: (slow) processes of economic and demographic deconcentration; stronger local-global articulation in the areas inserted in the currents of external trade; potential fragmentation of territory; growth of medium-sized cities beyond the traditional metropolitan areas, reproducing the old urban problems; new territorialities emerging in the areas of agricultural and mineral expansion; lower rates of rural-urban migration and the growth of urban-urban migration; the predominance of large corporations in the structuring of regional and urban spaces; establishment of infrastructures to increase the external productive integration; and, creating regional and urban policies directed at increasing the competitive integration in the country (MACEDO, 2010, p. 67-68).

It is within this general framework of transformation of the Brazilian economy and its territorial dynamics that the investments in transport infrastructure in post-2005 Brazil will be analyzed, among which the New Transnordestina Railroad has stood out.

\section{INFRASTRUCTURE AND TERRITORY}

For the reasons given above, infrastructural investments have gained prominence in the debate and formulation of economic policies in this century. Examples are the actions of the federal government through the National Logistics and Transport Program - PNLT (dated 2007), the Growth Acceleration Program - PAC 1 (2007-2010), PAC 2 (2011-2014), the Integrated Program of Logistics - PIL (2011-2014) and PIL 2 (2015-2018), in addition to the Initiative for Integration of South American Regional Infrastructure (IIRSA) and the National Integration and Development Axes (ENID) in the second Fernando Henrique Cardoso government (1999-2002). This latter synthesized well the concept of the use of the territory that guides all these initiatives: the identification of the dynamic foci of the economy and the constitution of a multimodal network to transfer regionalized productions to the external market. 
Despite the effective results of these initiatives, which will not be analyzed here, the relevant fact is the recognition that the country's type of foreign trade insertion, based on low-value products and large volumes for export, puts pressure on the public sector and private agents to increase investments to accelerate and reduce the cost of their stocking, storage and disposal, favoring the capital circulation phase. A quick reading of the official documents of the aforementioned programs or comparable private sector entities, such as those of the CNT (2014 and 2015), reveals the priority given to investments in transport infrastructure in the current pattern of capital reproduction in Brazil. This is because such investments increase the competitiveness of the economy, allow the efficient flow of mineral and grain production, and reduce logistical costs for all sectors, reducing the time of capital turnover.

Given the characteristics of this infrastructure, especially the long term maturity of its investments and the high capital / product ratio, which requires a great mobilization of financial resources, there is a temporal mismatch between the increase in productive capacity - located further and further away from the center of greatest consumption of final goods and the highest demand for intermediate goods in the country - and an improvement in the conditions for disposing of production, especially for the foreign market. Exports from the new producing areas are still very dependent on the ports of the Southeast and South regions as shown in Chart 1 which takes as an example some agricultural commodities.

Although manifest in all sectors of the economy, this problem seems to be more visible for the products that represent the core of Brazilian exports, because of their location in the interior and in areas with little economic density. The combination of low value-added, high production volumes and the long distances from the areas producing these commodities to the outflow routes for export and to the largest Brazilian urban centers requires real adaptations of these dynamic economic spaces to promote their exports.

An example illustrates this. Despite the increase in the participation of the Central-West region in grain production in Brazil, it can be observed that the ports of the Southeast and South, more specifically the ports of Santos / SP, Paranaguá / PR, Vitória / ES and São Francisco do Sul / SC continue to participate heavily in the export of the main products exported by the State of Mato Grosso (Figure 1), the main Brazilian producer of soybeans, soybean meal and corn, important products of the country's export agenda. Between 2000 and 2014, the State's exports of the three products (in tons) rose an average annual rate of $14.6 \%$. The production of soybeans and corn increased $11.8 \%$ between 2000 and 2013. For Brazil, during the same periods, this growth was $10.5 \%$ pa and $7.3 \%$ pa respectively. These figures indicate the role of these commodities in the country's export base and the importance of the Center-West for the trade balances. 


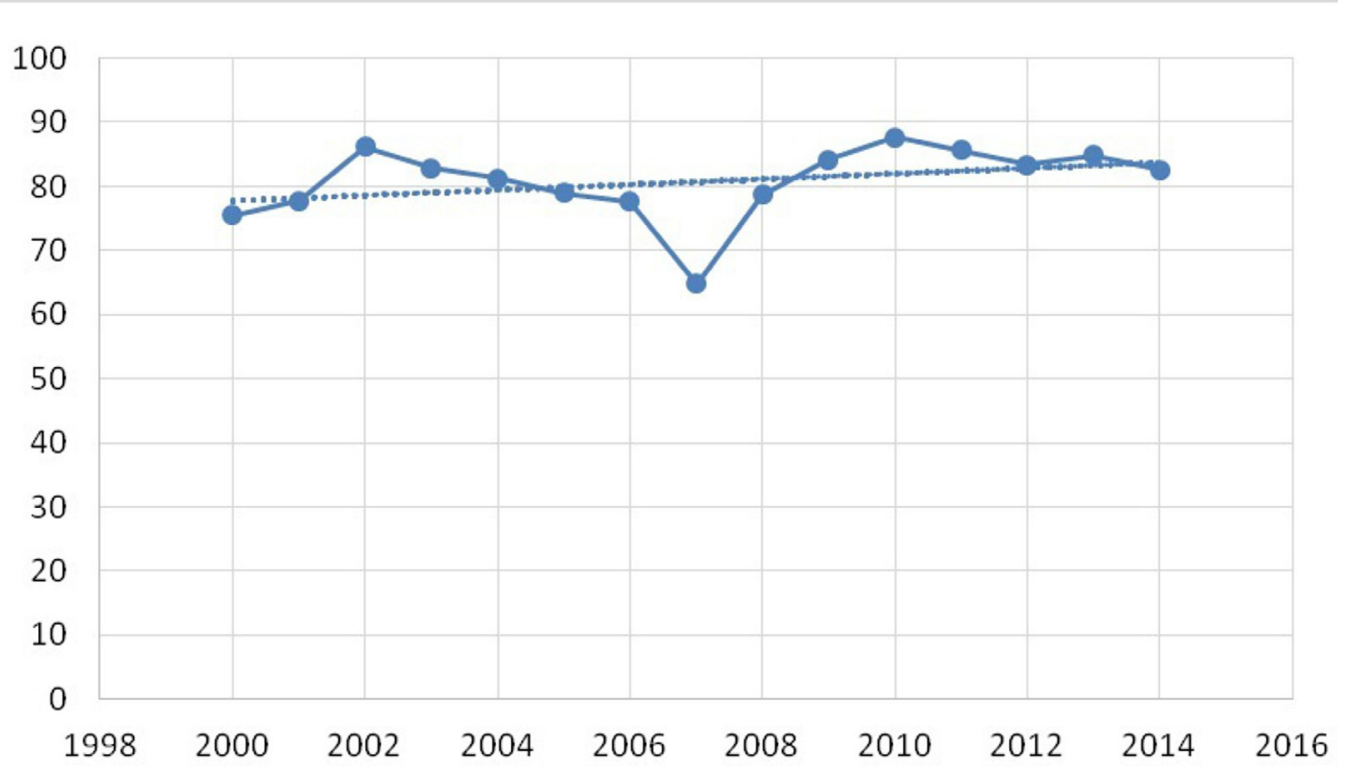

Figura 1 - Participation of South and Southeast ports in the flow of soy, soybean meal and maize from Mato Grosso - Years 2000-2014 (in\%)

Source - Ministry of Development, Industry and Foreign Trade (MDIC) Elaboration CEDE / IE / UNICAMP.

Figure 1 indicates a greater distance between the place of production and its flow to the exterior. This movement requires the federal government, producers and freight operators both to expand and diversify transportation infrastructure, since production in Brazil continues to be transported mainly by trucks, as alternatives to the exit of the product to the north of the country or other ports that may serve the production of the Brazilian Cerrado, such as that of Itaqui / MA or those of Suape / PE and Pecém / CE which, through the New Transnordestina, may be alternatives for the Matopiba region's exports, as will be highlighted below.

\section{THE NEW TRANSNORDESTINA}

This section analyzes the railway line in order to evaluate the potential of investment in logistics as a determinant of economic dynamism and possible productive and territorial restructuring. To this end, it is taken into account that as a private enterprise is involved, it is the economic density of its area of influence that determines its viability, despite its ultimate goal being to carry the grain and mineral production from the Northeastern Cerrado and part of the Center-west. Therefore, this analysis aims to relate the possible points of multimodal links and their respective areas of influence, highlighting their economic characteristics.

\section{GENERAL CHARACTERIZATION OF THE RAILWAY: HISTORY, INITIAL DESIGN AND SPECIFICITIES}

A regional project, linking the ports of Pecém / CE and Suape / PE to the city of Eliseu Martins / PI in the northeastern Cerrado, the construction of the New Transnordestina Railroad, part of the PAC, is the structural project that best demonstrates the integration of the market investment in infrastructure and logistics in the Northeast. In addition to its more general objectives of transporting grain and ore production from the Cerrado, the project is intended to complement the railway network in the region; its intermodal integration with several highways and the São Francisco waterway, in Petrolina / PE; the articulation of several agro-industrial regions with large ports, and consequently, the significant reduction of the distance by railway to the main cargo areas of the Northeast.

With a predicted initial investment of $\mathrm{R} \$ 11.3$ billion and completion estimated initially for 
2010, the project contemplates the construction of $650 \mathrm{~km}$ of new railway track between the cities of Missão Velha/CE - Salgueiro/PE - Trindade/PE - Eliseu Martins/PI. The engineering projects, environmental licenses, earthworks and drainage were the responsibility of the then Concessionaire Companhia Ferroviária do Nordeste - CFN, with the expropriations being the responsibility of the National Department of Transport Infrastructure - DNIT.

During the first year of PAC 1, an executive group was created between the Federal Government, State Governments (PE/CE/PI) and the Concessionaire - CFN to monitor the project. Cooperation agreements were signed between the DNIT / MT and the state governments to accelerate the process of expropriation, and for the Brazilian Institute of Environment and Renewable Natural Resources / Ministry of Environment - IBAMA/ MMA to accelerate the process of environmental licensing. However, successive delays in the execution of the works throughout period 2, led to the termination of the contract between the concessionaire and the construction company in 2013 and the signing of a new concession agreement on January 22, 2014. The concessionaire responsible for the works is Nova Transnordestina Logística SA - TLSA, a subsidiary of the Companhia Siderúrgica Nacional - CSN.

\section{THE NEW TRANSNORDESTINA AND SOCIOECONOMIC AND SPATIAL IMPACTS}

With the objective of relating the possible points of multimodal connections in the states contemplated by the works of the New Transnordestina and the economic and territorial impacts of their respective areas of influence, to evaluate the potential of logistic investment as a determinant of economic dynamism and productive and territorial restructuring, this work considers: : (i) for Pernambuco, the regionalization proposed by the Secretariat of Economic Development - SDEC called Development Regions; (ii) for Piauí, the regionalization proposed by the Secretariat of Planning - SEPLAN called Development Territories, and (iii) for Ceará, the regionalization proposed by the Secretariat of Planning and Management - SEPLAG called Planning Regions.

\section{a) Impacts in Pernambuco}

The first noteworthy development region in the state of Pernambuco is Araripe, where, according to the project, the Trindade logistics terminal will be located. In this region there are 37 of the 44 active gypsum mines in Brazil (MME and BM, 2009), a raw material for the production of plaster of Paris, as well as the main manufacturing industries responsible for supplying the markets of Pernambuco, Ceará, Bahia and São Paulo. The prospects for this gypsum region with the start of operation of the New Transnordestina should be analyzed from two different perspectives: (i) the mining companies involved in the extraction of gypsum; (ii) the calcination companies, transformers of gypsum in to powder (plaster of Paris), as well as the production of pre-cast and medical gypsum.

While the largest gypsum mineral producer in the country, this region is at least $700 \mathrm{~km}$ away from its largest consumer markets. The question that arises is the possibility of industrial development spreading outside this region, which a priori would only have developed there because it was isolated. Lacking two fundamental inputs for the calcination of gypsum - energy and water, and with low articulation between small and large companies in the region, by reducing distances the start of the New Transnordestina would increase the decentralization of production. The region would be led to a regressive specialization becoming merely a mining area since, despite the predominance of national groups - Grupo Prêmio and Siqueira, there are large multinational groups operating in this activity, especially the Lafarge and Knauf companies of French and German capital respectively, both appearing on the list of the 10 largest companies, with $85 \%$ of the world production capacity of gypsum plaster (MME and BM, 2009). The industry will lose out to regions closer to its consumer markets of plaster of Paris (São Paulo, Rio de Janeiro and Bahia) and suppliers of its basic inputs 
(energy and water). The gypsum ore would be transported by the New Transnordestina to where it could be converted at a lower cost, since in addition to the issues raised above, today there is the problem of the high cost of road transportation, since it is transportation without a return cargo. In this way, with the territorial integration of this market, the Araripe region must reinvent itself or its potential for growth will be exhausted. The articulation of local policies would be important to avoid this process, especially in the case of the extraction of gypsum that impacts the environment, such as the pollution of the air with gases and solid particles in gypsum mining caused by the detonation of explosives and the emissions generated by the diesel engines that drive the mining equipment. Furthermore, the transformation of gypsum into plaster emits $51,323 \mathrm{~kg}$ / hour of carbon dioxide during the firing and grinding of gypsum (MME and BM, 2009).

The second development region is the Sertão Central, where the municipality of Salgueiro is located, which will house an important logistical hub because it is the municipality where the BR-116 highway connects the southern markets of the country to Fortaleza / CE and the BR-232 highway connects the west to the east of Pernambuco. In addition, there is a highway that comes from the banks of the São Francisco River that connects it with Petrolina, a region that produces irrigated fruit. Therefore, it is a region of road junctions, all located in the northeastern semi-arid region. There are studies regarding the construction of a large refrigerator terminal to absorb the Petrolina / Juazeiro fruticulture and to dispose of it via rail transportation.

Currently the city has little economic relevance in the state besides basically consisting of a dry, arid region, counting only on traditional urban functions; its origin is linked to backcountry livestock, and the ancient cargo and muleteer route. Nowadays, it is considered important by scholars of the Pernambuco economy as the great bet in terms of development potential (verbal information). This is why the municipality, classified as Zone A Center according to REGIC/IBGE, should consolidate its position as an urban center of local reference, especially if investments expand and diversify its supply of services and trade that may increase its importance in its area of influence.

The third development region is the Southern Agreste, where there is an abundant dairy and poultry production, crossed by the BR-423 highway linking Garanhuns / PE - Paulo Afonso / BA. There are feasibility studies to establish a multimodal pole in this region so that maize to feed the region's cattle and poultry can be brought from the Cerrado by the New Transnordestina railway. Currently, the region is supplied by Argentina and Southeast Brazil, with imports entering the Port of Recife and transported to the area by highways.

The fourth multimodal link will take place in the Metropolitan Region of Recife (RMR), via the port of Suape through which the production will be disposed of by the railroad. Given its structural character for the entire economy of Pernambuco, the region of the Suape Industrial and Port Complex - CIPS has its own administration, although submitted to the SDEC. From the point of view of cargo movement to the port, the impact of the completion of New Transnordestina works would be positive, given the captive cargo of iron ore and grains that could be disposed of there. However, it could establish a greater process of economic concentration in the metropolitan area.

There are plans to build ore and multi-grains terminals in the port area. However, there is the issue of competition with the Port of Pecém / CE that will also have a connection of a branch of the New Transnordestina. From this point of view, Pecém / CE has a strategic competitive advantage: while Suape, which is classified as a public port, must bid for land concessions for the construction of terminals - model of Land Lord Port, Pecém only needs to make a direct lease. Therefore, it does not have to go through bureaucratic procedures with the federal government, since it is classified as a Private Use Terminal (TUP). In this case, a state TUP would be a legal contradiction.

A fifth possibility to densify and make transportation by the New Transnordestina economically viable would be the outflow of the production of the region's irrigated fruit farming of the São Francisco, concentrated in Petrolina. However, what has been said, but is not on any agenda, is that there is a railroad in the interior of Bahia, which connects Petrolina / PE to Salvador / BA, belon- 
ging to the Atlantic Center network, which could be linked to the New Transnordestina. The stretch from Feira de Santana / BA to Salvador / BA already exists. There was an economic, technical and environmental feasibility study contracted by the then Minister of Transport, Paulo Sérgio Passos, from Bahia, so that the Port of Aratu - BA could also benefit from this traffic (verbal information).

\section{b) Impacts in Piauí}

In Piauí, there are four development territories that will be directly impacted by the New Transnordestina railway: the Vale do Rio Guaribas and Vale do Canindé, in the semi-arid and the Tabuleiros of the Piauí and Itauteira rivers and the Chapada das Mangabeiras, in the Cerrado. In the development territories located in the semi-arid region, the project consists of the construction of multimodal terminals in the municipalities of Paulistana and Simplício Mendes, respectively. In spite of the low economic and social indicators, it is possible to notice the strong performance of agriculture in the region, with the economic base being founded on subsistence farming, small animal husbandry and cashew nut harvesting. However, as will be pointed out below, the expropriation process for the passage of the railroad has created social demands that question the project.

It should be noted that in Vale do Rio Guaribas there is the potential for the exploration of mineral resources, for example in the municipality of Pio IX, where there are marble deposits with differentiated texture and color, as well as high quality (blue, platinum, white and mixed); in the municipality of Fronteiras there is limestone for cement. The Secretariat of Mines and Energy of the State Government of Piauí also points to vermiculite and nickel as two abundant minerals in the Canindé Valley. The first is a mineral widely used in construction as a thermal insulation and waterproofing agent and the second is an important component in various metal alloys. The multimodal terminals of Paulistana and Simplício Mendes will serve as a means of disposing of the aforementioned minerals (BNE, 2012a), which may increase their role in the local urban network due to the possibility of expanding and diversifying the supply of services and trade.

In the development territories located in the Cerrado, the project is the construction of multimodal terminals in the municipalities of Itaueira and Eliseu Martins. It is in the Cerrado that agribusiness grows rapidly in the Northeast, making the Cerrado Piauí part of the great agricultural frontier of Matopiba.

The noteworthy development territories in this respect are the Chapada das Mangabeiras and the Alto Parnaíba Table, and the railroad will have an indirect impact on the latter since there is no multimodal terminal projected for this region. In the Chapada das Mangabeiras, the following municipalities stand out: Corrente, where cattle are the engine of the economy and whose cattle farming will gain a new impetus with the new classification of Piauí as an area free of foot-and-mouth disease, granted by the World Organization of Animal Health. Secondly, Currais, with 35 thousand open hectares in the Cerrados of Serras Laranjeiras and Pirajá with units built for processing of grains, mainly soybean. Palmeira do Piauí, where the sugarcane plantation is transforming the smallholdings of 200 families into an artisanal sugar cane rum pole. With regard to mineral resources, especially the municipalities of Gilbués, with diamond exploration and Curimatá and Santa Filomena with lime for agricultural use (CIDADE VERDE.COM, 2009).

In the Tabuleiro do Alto Parnaíba, the highlight is the municipality of Uruçuí, where modern agricultural technologies are used; and Baixa Grande do Ribeira, the state's largest soybean producer. Regarding mineral resources, the municipalities of Antônio Almeida and Porto Alegre do Piauí, with limestone for agricultural use, stand out. 


\section{c) 3.2.3. Impacts in Ceará}

The first noteworthy planning region in Ceará is Cariri, where, according to the projects, two multimodal terminals will be installed: one in Missão Velha and another in Lavras de Mangabeira. As Missão Velha is located in the area of the transposition of the waters of the São Francisco River, it is defended that the municipality has potential to agglutinate enterprises and the flow of regional production (BNE, 2012b). It is a municipality classified by the REGIC / IBGE as Local Center, the lowest in the urban hierarchy, but which can increase its centrality with the implementation of these investments.

However, although this region has fertile soils and available water, which favors the development of more diversified agricultural activities, for decades its economy has presented a declining trajectory compared to the state of Ceará. In part, this decline can be explained by the increase in the region's road infrastructure that allowed the entry of products from other regions at competitive prices. Recent studies indicate that a new round of reductions in transportation costs due to the reconfiguration of the state transportation matrix with the implementation of the New Transnordestina railroad may reinforce this pattern, maintaining the downward trend of Cariri's relative position in Ceará's economy, according to Justo (2010), even with recent incentives and investments in the footwear industry, which is focused on exports, especially by Grendene Ltda.

The second region that deserves to be highlighted, and which in turn already has relevant impacts in Ceará, is the Center South of the state, where there are plans to implement two other multimodal terminals: one in Iguatu and another in Acopiara. This planning region, while presenting characteristics similar to the Sertões region, has the areas of influence of the dams that deserve some distinction given the greater relative availability of water in relation to the sertão.

The city of Iguatu, classified by REGIC / IBGE as a Sub-Regional Center A, where work on the railroad has already begun, is historically highlighted by trade and services, offering support to more than 10 municipalities in its area of influence. It also produces bananas for the regional market, and with the installation of a large footwear plant also focused on the international market - Dakota SA, and there is already an intense movement of freight trains on its current railway line. In a debate on the New Transnordestina held in December 2016, the then Mayor Ednaldo Lavor stated that the work in Iguatu will give new directions for agricultural production, with the district of Alencar being one of the regions most benefited, by providing growth in agricultural exports and greater income for farmers in the region (IGUATUNEWS, 2016).

However, this process occurs in a contradictory manner. Hundreds of the rural producers of that district, where small properties predominate, are experiencing the division of their lands for the implantation of embankments, which in some points are over 12 meters high and the railroad itself that has an area of domain 80 meters wide. The separation of the low, productive land from the water sources for the livestock areas, those that need to be irrigated, from the corrals and the houses, makes it impossible to irrigate grains, forage, and the daily management of the livestock, as well as separating families and communities. Another general complaint relates to the value of the indemnification of the properties (DIÁRIO DO NORDESTE, 2015a).

The third planning region that will suffer direct impacts with the progress of the works is the Central Sertão of Ceará, which will have 4 multimodal terminals in Piquet Carneiro, Senador Pompeu, Quixeramobim and Quixadá. Although it is a region where the effects of droughts are felt more drastically, limiting the development of economic activities, the project to build a new line up to the Sertão de Crateús is worth mentioning, specifically in the municipality of Santa Quitéria, where the Itatiaia mine is located, the largest fired uranium mine in Brazil (46\% of the prospected uranium) and the sixth largest in the world, in addition to the deposits of iron ore, phosphate (used in the production of fertilizers and animal nutrition) and ornamental stones - white marble and granite (DIÁRIO DO NORDESTE, 2015b). Uranium is a major source of energy for nuclear power 
plants. However, the uranium extracted will be used for the production of yellowcake, a substance of great value in the international market (BNE, 2012b).

Although there is already an executive project for the new line between Nova Russas and Quixeramobim, passing through the city of Santa Quitéria, specialist studies point to Nova Russas - Quixadá as the main option for the construction of the stretch (BNE, 2012b). Quixadá has one of the commercial centers with the highest economic density in the central region of the state, classified as Sub-Regional Center A by Regic / IBGE. Poultry farming, along with trade, is the main sector of the economy. There are four large and medium-sized farms: Granja Feliana Ltda, Granja Abrigo Ltda, Quixadá Alimentos Avículas Ltda (QUIAVE) and Carneiro Avícola Ltda (CARVIL). CARVIL is the only one that also produces eggs, 90,000 units per day. The production is focused on consumption throughout the state of Ceará and also Piauí and Maranhão. Moreover, it is the location of the Quixadá Biodiesel Plant, in addition to the Mississipi Calçados SA factory, a subsidiary of Dakota SA.

There is also a proposal for the construction of a rail link connecting Quixadá / CE - Mossoró / $\mathrm{RN}$. The existence of large proven reserves of limestone in the Mato Grande, Vale do Açu, Mossoró and Chapada do Apodi, in Rio Grande do Norte, and part of the Vale do Jaguaribe, Ceará, and the importance of linking them with other productive infrastructure and means of product flow, in this case the large ports of the region, would justify the need for a feasibility study for the construction of this extension. For Ceará, the construction of this branch would facilitate the flow of limestone between the two states, contributing to the limestone supply of large enterprises installed or underway in the State, such as the cement industry, the refinery and the steel mill in the Industrial Complex and Port of Pecém - CIPP (BNE, 2012b).

Finally, the fifth planning region directly impacted by the railroad project is the Metropolitan Region of Fortaleza - RMF, with terminals provided in Caucaia and São Gonçalo do Amarante. The municipality of Caucaia already has good access to highways and railways, which makes it attractive in terms of logistics and support to the Maracanaú Industrial District. Access to the municipality of Caucaia takes place mainly by the BR-020 and CE-085 highways, as well as secondary roads. Caucaia is $16 \mathrm{~km}$ from Fortaleza; the two cities are interconnected through the José Martins Rodrigues bridge over the Ceará river, which connects the Leste-Oeste Avenue to the CE-225 state highway, interconnected with the BR-222. Since 2004, the municipality of Caucaia has been experiencing rapid population growth, as well as the execution of large economic projects that are being implemented in it and in its surroundings, such as the Cidade do Atacado (a wholesale outlet) that will house infrastructure to attract wholesalers and become a reference in large-scale trading in Latin America (BNE, 2012b), and the Cidade da Confecção, the largest clothing fair in the Northeast, creating about 24 thousand direct jobs.

The municipality of São Gonçalo do Amarante will be the final multimodal terminal to dispose of the production transported by the New Transnordestina railway, via the Pecém port, whose objective is to become the largest exporter of fruit and footwear in the country. In the CIPP, besides the port, the project also includes other large structuring projects, for example a refinery, a steel mill and an export processing zone - ZPE.

\section{PROJECT POSSIBILITY AND LIMITATIONS}

Infrastructure works in Brazil have suffered a direct impact from the economic crisis, the restrictive fiscal adjustment practiced since 2015 and the fall in international commodities prices which reduced the profitability of investments, especially those related to transport for exportation. In addition, Operation Lava Jato and the resulting political crisis has financially affected the largest contractors in the country responsible for the execution of the main infrastructure projects. The result was the deceleration or even the paralysis of most of them. 
However, in the specific case of New Transnordestina, the delays are prior to this and have become the norm. Machado (2016) points to the problems in the model adopted between the State and private enterprise as determinants for the slow pace of its execution. According to this researcher the work "was started outside of a clear legal framework, with poorly defined obligations and time limits" (Machado, 2016, p. 76) and with "contractual milestones, with unbalanced obligations between Union and concessionaire" (Machado, 2016, p. 76). In order to remedy these problems, a new concession contract was signed on January 22, 2014, which determined a 36-month deadline for the concessionaire to complete the work. All the same, once the deadline expired, the works are far from being completed. In addition, some problems remained, as was stated in the CGU report on the 2014 contract, which have also put at risk the project's economic and financial viability:

In this study all aspects related to the project were analyzed, from its conception to the contract signed with ANTT, as well as the contractual management of the railroad carried out by the Agency. As a result, inconsistencies were found in the negotiations that resulted in the signing of the railway concession contract, since ANTT did not demonstrate that it carried out previous studies and analyses that justified the public interest and demonstrated the maintenance of the economic-financial balance of the contract signed (CGU, 2016, page 26, italics in the original).

It is not the purpose of this paper to discuss the economic-financial viability of the project and / or its dependence on public resources, but instead to focus on the possible impacts on the socio-spatial organization resulting from the project. Firstly, it is worth mentioning the possible positive impacts that the conclusion of the railroad would have on the economy of some regions more directly related to the project. As demonstrated in item 3 of this study, in Pernambuco, the construction of a logistic pole housing a refrigerated terminal in the Central Sertão could reinforce the role of the municipality of Salgueiro in the sub-regional urban network of the state, but mainly allow the flow of the irrigated fruticulture of the Valley of São Francisco. In addition, the construction of a multimodal pole in the Southern Agreste could promote the consumption of grains from the northeastern Cerrado to feed livestock and poultry produced in the region, to the detriment of grain consumption from Argentina and Southeast Brazil entering the Port of Recife and then transported by road to the region. Finally, the RMR, through the Port of Suape, would have a higher volume of cargoes for export.

In Piauí, the conclusion of the project could both promote the agribusiness of the Chapada das Mangabeiras and Tabuleiro do Alto Parnaíba, the state's largest soybean producing region, as well as promote the potential for the exploitation of mineral resources in the region, such as marble, limestone for cement and agricultural use, vermiculite, nickel and diamond.

With regard to the state of Ceará, both the Cariri and the Center-South regions, because they have a greater relative availability of water in relation to other regions (the first one due to works of transposition of the São Francisco River and the second due to the reservoirs) they have a great potential for diversification of agricultural activities, with an emphasis on the potential for agglutination of enterprises (irrigated fruit for export) and regional production, thus providing greater incomes for farmers in the region. The positive impacts in the Central Sertão region will depend not only on the completion of the original railroad project, but on the construction of possible branches that would connect the Crateús Sertão with its fissionable uranium and its ore deposits of iron, phosphate, marble and granite, and the limestone producing region in Rio Grande do Norte. Finally, the RMF, through the Port of Pecém, would have a higher volume of cargo, reaching its goal of becoming the country's largest exporter of fruit and footwear.

However, in socio-spatial terms the limitations of the project seem to carry more weight than its possibilities. In Pernambuco, for example, we have seen that all of the Araripe's gypsum activity could be disarticulated, leading the region to a regressive specialization, thus becoming solely a mining area. An activity that, in addition to the irrelevant chain effects on the local economy, would accentuate atmospheric pollution from gases and solid particles, caused by the detonation 
of explosives and the diesel engines that drive the mining equipment. Another problem discussed above is the process of economic re-concentration in the RMR due to the increased investments and activities in CIPS.

In Ceará, some socio-spatial refutations are similar to those already listed for Pernambuco. In the Cariri region (as well as that of Araripe / PE) the reduction of transport costs may have a negative effect by reinforcing the trend of loss of relative positions in Ceará's economy. The RMF (like the RMR / PE), also has a certain process of economic re-concentration due to the investments and activities in the CIPP. But it is in the South Center region, where work has already begun, that one of the most perverse effects of this project can be seen: the disorganization of the way of life of small farmers in the areas where the tracks pass and / or in their direct environment, in spite of the process of popular organization in defense of the way of life endangered by the railroad, as is the case of the Movement of the Affected by Transnordestina Railroad in Alencar - MATA, in Iguatu / $\mathrm{CE}$, already mentioned previously. According to Barbosa (2015), this movement lists 12 problems that would be directly caused by the works, and that are, in a way, generalizable to other municipalities suffering the same effects. Among these problems: a) destruction of the vicinal roads; $b$ ) escape and loss of animals; c) risk of accidents; d) division of land and production difficulties; e) devaluation of rural properties (mainly smallholdings); (f) preventing the transit of animals from grazing areas on different sides; g) low price paid for expropriations; h) environmental problems. To these we could add: isolation of the properties from water sources; silting up of wells; absence of crossing points; therefore, mobility problems and the displacement of the population; risk to archaeological sites.

That is, to meet the transportation demands of the two main economic activities benefiting from the enterprise - agribusiness and the mineral extraction industry, both oriented to the outside and submitted to the interests of large global players, the Union has sanctioned a project with serious problems of contractual institutionalization and which puts at risk the family agriculture of the region. In the name of the new (old) developmentalism, the familiar symbiosis between specific national interest's groups (landowners and contractors), the State and international capital linked to the production and distribution of commodities in the external market, typical of the capital reproduction pattern previously presented as "productive specialization exporter".

Finally, the effect of the crisis on the execution of the project and on the labor market in the cities directly affected by the project must be emphasized. The first problem has already been highlighted: the delay in completion and more recently the work stoppage, as has been widely reported. The second aspect is linked to this and can be exemplified by the movement of the labor market in Salgueiro / PE. The original project provided for the construction of a logistics platform in this municipality that is crossed by BR 232 and 116 highways. Its location and its role in the sub-regional urban network in Pernambuco, as a Zone A Center, according to the REGIC / IBGE classification, led it to host the offices of the companies responsible for the construction of the railway and the transposition of the São Francisco River. In 2010, the total number of workers formally hired in the construction sector in the municipality was 9.5 thousand. By 2015, this number had dropped to 346 , which represented $0.4 \%$ of the state's total in the sector, at $7.5 \%$ in 2010 . The municipality's GDP follows the pace of railroad investment: R \$ 382 million in 2009 (at current prices); R \$ 858 million (2010); R \$ 882 million (2011); R \$ 799 million (2012) and R \$ 658 million (2013). In 2014, with the new contract and the resumption of works, it will grow again (R $\$ 773$ million), but will probably fall in the following years, when the IBGE municipal GDP data is released, due to the economic crisis and the fiscal adjustment. 


\section{FINAL CONSIDERATIONS}

Economic infrastructures are decisive for the transformation of a given region, although they cannot be directly pointed to as a sufficient condition for the promotion of economic development, as is commonly done. On the contrary, it can simultaneously promote productive transformations, increase competitiveness and deepen the dependence of a country or region, maintaining conditions of underdevelopment, even with the increase in the level of production and income.

Its impact on economic development will depend on the pattern of reproduction of the dominant capital in a given socio-spatial formation and the political, economic and social project that is established within the same formation, from the disputes between the different interest groups that materialize in their capacities (or limitations) to influence economic policy (as well as regional and urban), set priorities for investments and access public funds. That is, it depends on the class struggle at each specific conjuncture.

It cannot be overstated that a given transport infrastructure can serve to integrate and increase the articulation of the internal market with productive regional diversification, or can function as a mere corridor that guarantees the export of specialized regional productions by linking local activities directly to the global market. In either case, the results in terms of economic development can be (and often are) very different.

From the spatial point of view, as Macedo $(2015,44)$ points out, infrastructure organizes the territory, it forms networks that connect countries, cities and regions to the same logic of accumulation and influences the territorial division of labor, productive specializations, the complementarities between different regions and socio-spatial patterns of structuring, besides (re)defining the use and occupation of the land. As there is no investment in infrastructure that is not territorially impacting, it is important to carefully observe its social and environmental effects, which ultimately indicate the interests that prevail around it. This process occurs in a contradictory and conflicting way, since it is movement by the interests of the hegemonic groups, mainly in opposition to others, of groups of lesser economic and political strength.

The New Transnordestina has all these signs. The re-emergence of the project, which dates originally from the nineteenth century, takes place in a new phase of capital reproduction in the Brazilian economy, with its own specificities. A phase that requires infrastructural investments, especially in transport, to increase the connection of the dynamic areas producing agricultural and mineral commodities for export to oblige the pressures of international capital. These hegemonic interests are amalgamated into a symbiosis of fractions of national capital, the state and capital-imperialism transforming and constituting a territory that adapts itself to attend not to its people, but to capitalist accumulation. Nevertheless, it doesn't have to be that way.

\section{BIBLIOGRAPHIC REFERENCE}

ALHEIROS, J. Jaime Alheiros. Diretor de Planejamento e Urbanismo do Complexo Industrial e Portuário de Suape. Entrevista concedida à autora em 13 de novembro de 2014.

ANDRADE, M. O. Maurício Oliveira de Andrade. Professor da pós-graduação em infraestrutura de transportes da Universidade Federal de Pernambuco. Entrevista concedida à autora em 11/11/2014.

ARÁUJO, S. M. S, Gargalos de desenvolvimento e ações do estado no pólo gesseiro do Araripe. Revista Mercator, Fortaleza, v. 9, n. 19, mai-ago. 2010, p. 65-79.

ARUTO, P. C. A formação socioespacial dependente a partir da superexploração da força de trabalho: uma abordagem metodológica. 2015. 119 fls. Dissertação (Mestrado em Desenvolvimento Econômico) Instituto de Economia, Universidade Estadual de Campinas, Campinas, 2015.

ARUTO, P. C.; GOMES JR., E. Padrão de reprodução do capital exportador de especialização produtiva e 
a produção social do espaço nas regiões brasileiras. Revista Eletrônica Documento/Movimento, Cuiabá, v. 20, n. 1, dez. 2016, p. 226-238. Disponível em: <http://200.129.241.80/ndihr/revista/revistas-anteriores/ revista-dm-20.pdf >. Acesso em: 22 jan. 2017.

BIACHI, A. P. T. Condicionantes e Articulações dos Investimentos no Complexo Industrial e Portuário de Suape - PE. 2015.172 fls. Dissertação (Mestrado em Desenvolvimento Econômico) - Instituto de Economia, Universidade Estadual de Campinas, Campinas, 2015.

BANCO DE DESENVOLVIMENTO DO NORDESTE. Caracterização e análise dos sistemas Produtivo e macrologístico na região Nordeste enquanto suporte à localização de empreendimentos: foco no papel da Ferrovia transnordestina. Tomo V - Estado do Piauí. Fortaleza, 2012a.

BANCO DE DESENVOLVIMENTO DO NORDESTE. Caracterização e análise dos sistemas Produtivo e macrologístico na região Nordeste enquanto suporte à localização de empreendimentos: foco no papel da Ferrovia transnordestina. Tomo III - Estado do Ceará. Fortaleza, 2012b.

BORGES, A.; SCARMUZZO, M. VIANNA, L. F. Obra da Transnordestina não tem prazo para ser concluída. Estado de S. Paulo, São Paulo, 16 fev. 2017. Disponível em: http://economia.estadao.com.br/ noticias/negocios,obra-da-transnordestina-nao-tem-prazo-para-ser-concluida,70001667500. Acesso em: 16 fev. 2017.

BRANDÃO, C. A.; GALVAO, A. C. F. Fundamentos, motivações e limitações da proposta governamental dos Eixos Nacionais de Desenvolvimento e Integração. In: GONÇALVES, M. F.; BRANDÃO, C. A.; GALVÃO, A. C. (Org.). Regiões e Cidades, Cidades nas Regiões - o desafio urbano-regional. São Paulo: Editora da UNESP, 2003, v. 1, p. 187-205.

CAMELO FILHO, J. V. A implantação e consolidação das estradas de ferro no nordeste brasileiro. 2000. 246 fls. Tese (Doutorado em Ciências Econômicas) - Instituto de Economia, Universidade Estadual de Campinas, Campinas, 2000.

CAMELO FILHO, J. V. As ferrovias do Nordeste: entre os limites econômicos e a política de controle e ocupação do interior do país. IN: GOULARTI FILHO. A; QUEIROZ, P. R. C. (Org.). Transportes e formação regional: contribuições à história dos transportes no Brasil. Dourados: Ed. UFGD, 2011, p. 139-180. CIDADE VERDE.COM. Cerrado piauiense é a região que mais cresce e o $2^{\mathbf{0}}$ PIB do PI. Disponível em: http://cidadeverde.com/noticias/46513/cerrado-piauiense-e-a-regiao-que-mais-cresce-e-o-2-pib-do-pi. Acessado em: 29 de janeiro de 2017.

COMITÊ GESTOR DO PAC. Palácio do Planalto. Balanço PAC - Cartilha Estadual/PE. Brasília, Diversas Datas.

CONFEDERAÇÃO NACIONAL DO TRANPORTE. Plano CNT em logística. Brasília, 2014.

CONFEDERAÇÃO NACIONAL DO TRANPORTE. Entraves logístico ao escoamento da soja e milho. Brasília, 2015.

CONTROLADORIA GERAL DA UNIÃO. Relatório n. 201407822. Dispõe sobre os resultados dos exames realizados quanto ao levantamento de informações sobre o contrato de concessão da Ferrovia "Nova Transnordestina", celebrado, em 22 de janeiro de 2014. Brasília, 20 abr. 2015. Disponível em $<$ http://auditoria. cgu.gov.br $>$. Acesso em 22 de jan. 2017.

CORREA, R. L. Organização espacial e região. São Paulo: Ática, 1986.

DIÁRIO DO NORDESTE. Construção da Nova Transnordestina causa impacto em Iguatu. Disponível em: http://diariodonordeste.verdesmares.com.br/cadernos/regional/construcao-da-NovaTransnordestina-causa-impactos-em-iguatu-1.1327345. Acessado em: 29 de janeiro de 2017.

DIÁRIO DO NORDESTE. Obras em Itatiaia devem começar em julho. Disponível em: http://diariodonordeste.verdesmares.com.br/cadernos/negocios/obras-em-itataia-devem-comecar-em-julho-1.20315. Acessado em: 29 de janeiro de 2017.

FILHO FIGUEIREDO, J. de. História do Cariri. Fortaleza: UFC, 4 volumes, 2010.

IGUATUNEWS. Em Brasília Ednaldo participa de debate sobre a Transnordestina, Disponível em: http://iguatunews.com.br/press/em-brasilia-ednaldo-participa-de-debate-sobre-a-NovaTransnordestina/. Acessado em: 29 de janeiro de 2017. 
MACEDO, F. C M.; MORAIS, J. M. L., LIMA JUNIOR, F. Ó. Ceará: Economia, Urbanização e metropolização. Crato: RDS Editora/Urca, 2014.

JUSTO, W.R. Possíveis impactos da ferrovia Transnordestina na economia do Cariri cearense: uma abordagem do modelo centro-periferia. Revista de Desenvolvimento do Ceará, Fortaleza, n.1, outubro de 2010, p. $118-135$.

LESSA, C. Infraestrutura e logística. In: CARDOSO JR., J. C. (Org.) Desafios ao desenvolvimento brasileiro: contribuições do conselho de orientação do Ipea. Brasília: IPEA, 2009. p. 77-100. Livro 1.

LIMA JUNIOR, F. do O' de. Estrutura produtiva e rede urbana no Estado do Ceará durante o período de 1980-2010. 2014. 264 fls. Tese (Doutorado em Desenvolvimento Econômico) - Instituto de Economia, Universidade Estadual de Campinas, Campinas, 2014.

LOPES, J.C.R. O transporte ferroviário no Nordeste brasileiro e o potencial de desenvolvimento do sudoeste do estado do Piauí. 2016. 121 fls. Tese (Doutorado em Geografia) - Universidade Estadual Júlio de Mesquita, Rio Claro, 2016.

MACEDO, F. C. Inserção externa e território: impactos do comércio exterior na dinâmica regional e urbana no Brasil (1989-2008). 2010.302 fls. Tese (Livre-Docência) - Instituto de Economia, Universidade Estadual de Campinas, Instituto de Economia, Campinas, 2010.

MACEDO, F. C. Economia, Transformações Territoriais e Infraestrutura no Brasil. Conjuntura \& Planejamento, Salvador, jul./set. 2015, p. 43-52. Disponível em: $<$ http://www.sei.ba.gov.br/index.php?option=com content\&view=article\&id=81\&Itemid=110 > . Acesso em: 22 jan. 2017.

MACHADO, R. A. Condicionantes institucionais à execução do investimento em infraestrutura no Brasil: estudo de caso sobre a implantação da Transnordestina. Texto para Discussão/IPEA, Brasília/Rio de Janeiro, n. 2.551, nov. 2016. Disponível em: <http://www.ipea.gov.br/portal/index.php?option=com_co ntent\&view=article\&id=28945\&Itemid=406>. Acesso em: 19 jan. 2017.

MARINI, R. M. O ciclo do capital na economia dependente. In: OSORIO, J. et. al. (Orgs.). Padrão de reprodução do capital. SP: Boitempo, 2012, p. 21-36.

MINISTÉRIO DE MINAS E ENERGIA e BANCO MUNDIAL. Desenvolvimento de estudos para elaboração do plano duodecenal (2010 - 2030) de geologia, mineração e transformação mineral. Produto 24 gipsita. Relatório técnico 34 perfil da gipsita. Projeto de assistência técnica ao setor de energia. Setembro de 2009. Disponível em: HTTP://WWW.MME.GOV.BR/DOCUMENTS/1138775/1256650/p24_rt34_pERFIL_DA_gIPSITA.PDF/CDE62398-0912-43C2-AF79-27C0651D1412. Acessado em fevereiro de 2017.

OSORIO, J. Padrão de reprodução do capital: uma proposta teórica. In: OSORIO, J. et. al. (Orgs.). Padrão de reprodução do capital. SP: Boitempo, 2012a, p. 37-86.

OSORIO, J. América Latina: o novo padrão exportador de especialização produtiva - estudo de cinco economias da região. In: OSORIO, J. et. al. (Orgs.). Padrão de reprodução do capital. SP: Boitempo, 2012b, p. 103-133.

PEREIRA JÚNIOR, E. Território e Economia Política: uma abordagem a partir do novo processo de industrialização do Ceará. 2011. 450f. Tese (Doutorado em Ciências e Tecnologia) - Universidade Estadual Paulista, Presidente Prudente, 2011.

SAMPAIO, D. Desindustrialização e estruturas produtivas regionais no Brasil. 2015. 267 fls. Tese (Doutorado em Desenvolvimento Econômico) - Instituto de Economia, Universidade Estadual de Campinas, Campinas, 2015.

SAMPAIO, D. MACEDO, F. C. Desindustrialização e impactos regionais no Brasil: uma análise preliminar. Conjuntura \& Planejamento, n. 184, jul.-set. 2014, p. 49-57. Disponível em: <http://www.sei.ba.gov.br/ index.php?option=com_content\&view=article\&id=81\&Itemid=110 >. Acesso em: 22 jan. 2017.

SANTOS, M.; SILVEIRA, M. L. Brasil: território e sociedade no início do século XXI. São Paulo: Editora Record, 2001, 474 pp.

SANTOS, M. Sociedade e espaço: a formação social como teoria e como método. Boletim Paulista de Geografia. São Paulo, n. 54, p.35-59, jun de 1977. 
SORMANI, H. Formación social y formación espacial: hacia uma dialética de los asentamientos humanos. Estudos Sociales Centro Americanos, Costa Rica, 6 (17):14, maio/ago, 1977.

VALENTE, J. A. Infraestrutura, transportes e mobilidade territorial. São Paulo: Editora da Fundação Perseu Abramo (Coleção Projetos para o Brasil), 2013. 